\title{
Anthropogenic 236U in Danish Seawater: Global Fallout versus Reprocessing Discharge
}

Qiao, Jixin; Steier, Peter ; Nielsen, Sven Poul; Hou, Xiaolin; Roos, Per; Golser, Robin

Published in:

Environmental Science and Technology

Link to article, DOI:

10.1021/acs.est.7b00504

Publication date:

2017

Document Version

Peer reviewed version

Link back to DTU Orbit

Citation (APA):
Qiao, J., Steier, P., Nielsen, S. P., Hou, X., Roos, P., \& Golser, R. (2017). Anthropogenic ${ }^{236} \mathrm{U}$ in Danish Seawater: Global Fallout versus Reprocessing Discharge. Environmental Science and Technology, 51(12), 6867-6876. https://doi.org/10.1021/acs.est.7b00504

\section{General rights}

Copyright and moral rights for the publications made accessible in the public portal are retained by the authors and/or other copyright owners and it is a condition of accessing publications that users recognise and abide by the legal requirements associated with these rights.

- Users may download and print one copy of any publication from the public portal for the purpose of private study or research.

- You may not further distribute the material or use it for any profit-making activity or commercial gain

- You may freely distribute the URL identifying the publication in the public portal 


\section{Anthropogenic ${ }^{236} \mathrm{U}$ in Danish Seawater: Global Fallout vs. Reprocessing}

\section{Discharge}

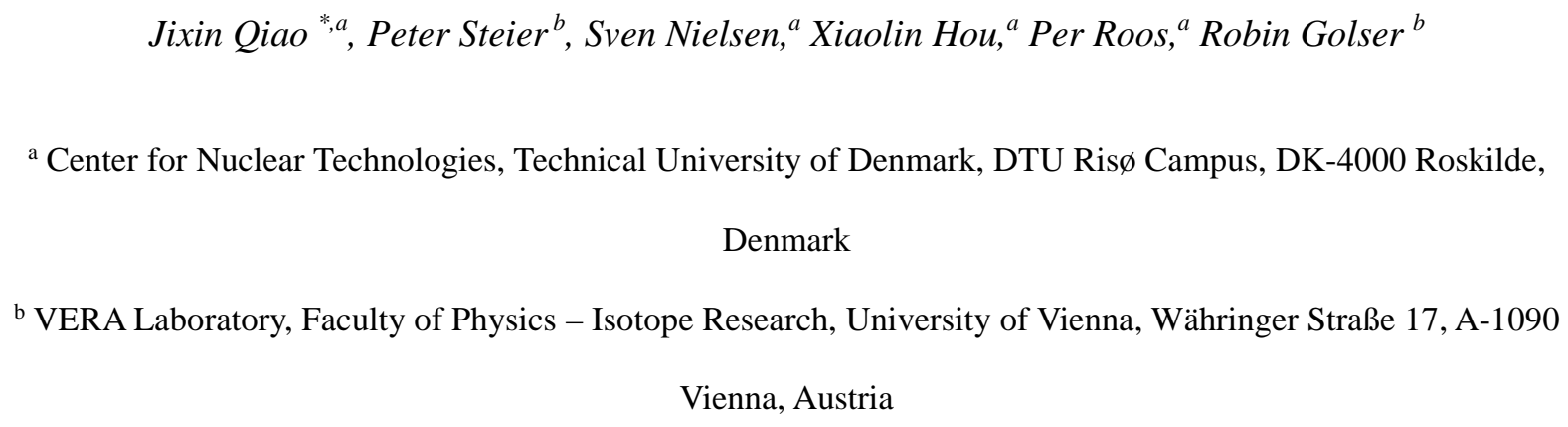

\section{ABSTRACT}

This work focuses on the occurrence of ${ }^{236} \mathrm{U}$ in seawater along Danish coasts, which is the solely water exchange region between the North Sea/Atlantic Ocean and the Baltic Sea. Seawater collected in 2013 and 2014 were analysed for ${ }^{236} \mathrm{U}$ (as well as ${ }^{238} \mathrm{U}$ and ${ }^{137} \mathrm{Cs}$ ). Our results indicate that ${ }^{236} \mathrm{U}$ concentrations in Danish seawater are distributed within a relatively narrow range of (3.6-8.2) $\times 10^{7}$ atom/L and to certain extent independent of salinity. ${ }^{236} \mathrm{U} /{ }^{238} \mathrm{U}$ atomic ratios in Danish seawater are more than 4 times higher than the estimated global fallout value of $1 \times 10^{-9}$. The levels of ${ }^{236} \mathrm{U} /{ }^{238} \mathrm{U}$ atomic ratios obtained are comparable to those reported for the open North Sea, and much higher than several other open oceans worldwide. This indicates, besides the global fallout input, the discharges from the two major European nuclear reprocessing plants are dominating sources of ${ }^{236} \mathrm{U}$ in Danish seawater. However, unexpected high ${ }^{236} \mathrm{U} /{ }^{238} \mathrm{U}$ ratios as well as high ${ }^{236} \mathrm{U}$ concentrations were observed at low salinity locations of the Baltic Sea. While this feature might be interpreted as a clue for another significant ${ }^{236} \mathrm{U}$ input in the Baltic Sea, but may also be caused by the complexity of water currents or slow turnover rate. 
24 - First results of ${ }^{236} \mathrm{U}$ in the mixing area of the North Sea/the Atlantic Ocean and the Baltic Sea are 25 reported.

26 - Anthropogenic ${ }^{236} U$ dominates Danish seawater with a relatively homogeneous distribution of ${ }^{236} U$

27 concentration independent of salinity.

28 - Relatively high levels of ${ }^{236} U$ concentrations and ${ }^{236} U /{ }^{238} U$ atomic ratios are observed in Danish 29 seawater, which might need to be taken into account when carry out tracer applications of ${ }^{236} U$ in the $30 \quad$ North Atlantic-Arctic Ocean.

31 - If ${ }^{236} \mathrm{U}$ derived from the early era of reprocessing was stored or deposited in the sediment of the 32 Baltic Sea and serves now as a major source, ${ }^{236} \mathrm{U}$ might be a potentially useful tracer to investigate 33 the turn over and exchange of the water in Baltic Sea, as well as the interaction between the sediment 34 and water in the Baltic Sea. 
$37{ }^{236} \mathrm{U}\left(\mathrm{t}_{\frac{1}{2}}=2.34 \times 10^{7}\right.$ y) is produced by thermal neutron capture of the omnipresent ${ }^{235} \mathrm{U}$ via $(\mathrm{n}, \gamma)$ 38 reactions, as well as through ${ }^{238} \mathrm{U}$ (n, 3n) ${ }^{236} \mathrm{U}$ reactions with fast neutrons. A very minor amount (about 35 $39 \mathrm{~kg}$ ) of natural ${ }^{236} \mathrm{U}$ was estimated on the Earth's crust surface, mainly in uranium ores, ${ }^{1}$ while the majority 40 (more than $1000 \mathrm{~kg}$ ) of ${ }^{236} \mathrm{U}$ in the environment originate from anthropogenic nuclear activities, e.g., 41 fallout from atmospheric nuclear weapons testing and discharges from nuclear facilities. ${ }^{2,3}$

42 Since ${ }^{236} \mathrm{U} /{ }^{238} \mathrm{U}$ isotopic ratios together with the occurrence of other minor $\mathrm{U}$ isotopes carry key 43 signatures for uranium sources, ${ }^{236} \mathrm{U}$ has been recognized as a valuable tracer in nuclear safeguards, 44 geology and environmental studies. ${ }^{3-15}$ In recent years, the potential of ${ }^{236} \mathrm{U}$ as a new oceanographic tracer 45 has been promoted by several studies. ${ }^{1,16-21}$ Based on its conservative behavior and well-established 46 knowledge regarding all other naturally occurring $U$ isotopes in the ocean, ${ }^{236} U$ would provide an 47 additional transient signal of water masses. In combination with other anthropogenic tracers (e.g., CFCs, $48{ }^{3} \mathrm{H},{ }^{14} \mathrm{C},{ }^{134} \mathrm{Cs},{ }^{137} \mathrm{Cs},{ }^{129} \mathrm{I},{ }^{99} \mathrm{Tc}$ ), tracer applications of ${ }^{236} \mathrm{U}$ in the world oceans would provide a clearer 49 picture illustrating water mass movements, circulation and mixing patterns of different water flows, 50 which are important and challenging aspects in oceanography. Even though significant work has been 51 devoted to assess its distribution and to develop tracer applications of anthropogenic ${ }^{236} \mathrm{U}$ in the marine 52 environment, worldwide ${ }^{236} U$ data is limited; especially the distribution of ${ }^{236} U$ in regional seas, such as 53 the Baltic Sea is not well known. A major challenge in applying ${ }^{236} \mathrm{U}$ to oceanographic tracer studies is to 54 define the source terms of ${ }^{236} \mathrm{U}$ in the marine environment.

55 To be used as a reliable tracer, knowledge on the source terms of ${ }^{236} \mathrm{U}$ in the Ocean is a prerequisite. It 56 was estimated that global fallout of the atmospheric nuclear weapons testing has released $1000-1400 \mathrm{~kg}$ 57 of ${ }^{236} \mathrm{U}$ to the environment. ${ }^{17,20}$ It was estimated that about $10^{6} \mathrm{~kg}$ of ${ }^{236} \mathrm{U}$ has been produced in nuclear 58 power reactors, of which the majority still remain in unprocessed nuclear waste and only a small 59 proportion is released from the reprocessing plants. ${ }^{3}$ The North Atlantic and Arctic Oceans have been 60 identified as regions of special oceanographic interest, due to their role in the thermohaline 
61 circulation. ${ }^{19,22}$ Several studies using various tracers have been applied in these domains over the past 62 decades, including natural and anthropogenic radionuclides. ${ }^{236} \mathrm{U}$ would be another conservatively 63 behaving water mass tracer to use. However, the source terms of ${ }^{236} \mathrm{U}$ especially in the region of the North 64 Atlantic and Arctic Oceans are not yet clear and the environmental distribution of anthropogenic ${ }^{236} \mathrm{U}$ is 65 still not sufficiently investigated.

66 Several studies have reported ${ }^{236} \mathrm{U} /{ }^{238} \mathrm{U}$ ratios up to $10^{-8} \mathrm{in}$ young surface waters and sediments in 67 Northwest Europe.$^{18,19}$ Anthropogenic ${ }^{236} \mathrm{U}$ has also been detected at more than $4000 \mathrm{~m}$ depth in the 68 equatorial Atlantic Ocean. ${ }^{1,20}$ The two European nuclear fuel reprocessing facilities La Hague (France) 69 and Sellafield (UK) are considered as important ${ }^{236} \mathrm{U}$ sources in the Atlantic-Arctic Ocean. In seawater 70 collected in 1993 from the Irish Sea affected by the radioactive waste release from the Sellafield 71 reprocessing plant, ${ }^{236} \mathrm{U} /{ }^{238} \mathrm{U}$ atomic ratios were reported to be $2 \times 10^{-6} .{ }^{7}$ Elevated ${ }^{236} \mathrm{U}$ levels $\left({ }^{236} \mathrm{U} /{ }^{238} \mathrm{U}\right.$

72 atomic ratios reached to $2 \times 10^{-8}$ in 2009) were also observed in seawater near the La Hague reprocessing 73 plant. ${ }^{18}$ However, due to limited documentation of the uranium discharge history of the two European 74 nuclear reprocessing plants, little is known about the actual ${ }^{236} U /{ }^{238} U$ ratios in the discharges from the 75 reprocessing plants. The only available data is from La Hague, that contributes a minor part to the total 76 amount of ${ }^{236} \mathrm{U}$ released into the North Sea. ${ }^{18,19,23}$ Studies have indicated that the spatial distribution of $77 \quad{ }^{236} \mathrm{U}$ in the North Sea is consistent with a simple model that involves the two reprocessing plants as the 78 sole sources of ${ }^{236} \mathrm{U}$ in this marine region. ${ }^{18}$ However, more experimental data are needed to constrain 79 parameters used in the model in order to reconstruct the discharge history of the two reprocessing plants.

80 Furthermore, the understanding of uranium environmental behavior in the mixing process of different 81 water currents is another key issue in tracer studies utilizing ${ }^{236} \mathrm{U}$. Uranium is known to be generally 82 conservative in open oceans under oxygenated conditions. ${ }^{24,25}$ Whereas, several studies have indicated 83 that the behavior of uranium is not strictly conservative in anoxic water systems. ${ }^{25,26}$ For example, in the 84 deeper intermittently anoxic basin of the Baltic Proper (e.g., Gotland Deep, being anoxic below $200 \mathrm{~m}$ 85 depth since 1979), uranium was reported to be removed from the water phase and incorporated into the 86 sediment. ${ }^{26}$ The anoxic intermediate section of the Black Sea contains less $U(1.3 \mu \mathrm{g} / \mathrm{kg})$ compared to the 

97 Sea.

surface water (1.8-2.0 $\mu \mathrm{g} / \mathrm{kg})$, while the bottom sediments in the central part are enriched in uranium (10$12 \mathrm{ppm}){ }^{27,28}$ It has been suggested that the mechanism for withdrawal of dissolved uranium from the water phase are reduction of uranium (VI) to uranium (IV), followed by precipitation as $\mathrm{UO}_{2}$, or adsorption on a reactive phase, e.g., organic material..$^{25,26}$

The Danish Straits are the sole water exchanging area between the oceanic North Sea/the Atlantic Ocean and the brackish Baltic Sea. Saline water from the North Sea flows near the bottom into the Kattegat, where outflow water of lower salinity from the Baltic remains on the surface. The Danish Straits provide unique advantages to study water mixing between the saline North Sea water and brackish Baltic Sea water and the dispersion of uranium in different water systems, especially transport of ${ }^{236} \mathrm{U}$ discharged from Sellafield and La Hague reprocessing plants to the North Atlantic Ocean and the Baltic

In this work, seawater samples collected along the Danish coast were analyzed for ${ }^{236} \mathrm{U}$ and other radionuclides $\left({ }^{238} \mathrm{U}\right.$ and $\left.{ }^{137} \mathrm{Cs}\right)$. We aimed to investigate the mixing behavior and the source terms of ${ }^{236} \mathrm{U}$ in the North Sea - Baltic Sea region using the levels and distribution pattern of ${ }^{236} \mathrm{U}$ obtained in this work, thus contribute to assess the dispersion of anthropogenic ${ }^{236} \mathrm{U}$ in the Atlantic-Arctic Ocean.

\section{MATERIALS AND METHODS}

Standards, reagents and samples. Uranium standard solution $\left(1.000 \mathrm{~g} / \mathrm{L}\right.$ in $\left.2 \mathrm{~mol} / \mathrm{L} \mathrm{HNO}_{3}\right)$ was purchased from NIST (Gaithersburg, MD), which was used after dilution as a standard for the ICP-MS measurement to quantify ${ }^{238} \mathrm{U}$ in seawater. All reagents used in the experiment were of analytical reagent grade and prepared using ultra-pure water $(18 \mathrm{M} \Omega \cdot \mathrm{cm})$. UTEVA resin $(100-150 \mu \mathrm{m}$ particle size) was purchased from Triskem International, Bruz, France and packed in 2-mL Econo-Columns $(0.7 \mathrm{~cm}$ i.d. $\times 5$ cm length, Bio-Rad Laboratories Inc., Hercules, CA) for the chemical purification of uranium isotopes. Surface and bottom seawater samples collected from Danish coasts in the summer (June-July) of 2013 and 2014, respectively, were analyzed for salinity, ${ }^{137} \mathrm{Cs},{ }^{238} \mathrm{U}$ and ${ }^{236} \mathrm{U}$. Details of samples information are summarized in Table S-1 and a map of the sampling locations is shown in Figure 1. 
112 Analytical methods for determination of ${ }^{137} \mathbf{C s},{ }^{238} \mathbf{U}$ and ${ }^{236} \mathbf{U}$. To determine ${ }^{137} \mathrm{Cs}$ in each seawater,

$11345 \mathrm{~L}$ of seawater was transferred to a flask and acidified to $\mathrm{pH} 2$ with concentrated $\mathrm{HNO}_{3}$. $30 \mathrm{mg}$ of Cs

114 carrier (as $\mathrm{CsCl}$ ) and $50 \mathrm{~g}$ of ammonium 2-molybdophosphate (AMP) was added and the sample was

115 stirred for $1 \mathrm{~h}$ for the adsorption of Cs by AMP. After settling for overnight, the supernatant was discarded

116 and the remaining slurry was filtered and dried at $105^{\circ} \mathrm{C}$ in an oven for overnight. The AMP powder was

117 weighed to calculate the chemical yield of Cs and then measured by gamma spectrometry using HPGe

118 (high-purity germanium) detectors with about 40\% relative efficiency. To reach acceptable levels of

119 detection limits and measurement uncertainties, each sample was counted for $24 \mathrm{~h}$.

120 The concentration of ${ }^{238} \mathrm{U}$ in seawater was directly measured by ICP-MS (X Series ${ }^{\mathrm{II}}$, Thermo Fisher

121 Scientific, Waltham, MA) after 10 times dilution. The ICP-MS instrument was equipped with an Xt-

122 skimmer core and a concentric nebuliser under hot plasma conditions. The typical operational conditions

123 of the instrument have been given elsewhere. ${ }^{29}$ Indium (as $\mathrm{InCl}_{3}$ ) was used as an internal standard and 0.5

$124 \mathrm{~mol} / \mathrm{L} \mathrm{HNO}_{3}$ solution was used as a washing solution between consecutive assays.

125 The detailed analytical method for the determination of ${ }^{236} \mathrm{U}$ in seawater has been reported elsewhere. ${ }^{30}$

126 It should be noted that the seawater samples collected in 2013 were not filtered before analysis while the

127 samples collected in 2014 were filtered through a Munktell 00K paper filter. In short, to 5 or $10 \mathrm{~L}$

128 seawater, conc. $\mathrm{HNO}_{3}$ was added to adjust $\mathrm{pH}$ to 2 and purified $\mathrm{FeCl}_{3}$ solution $(0.05 \mathrm{~g} / \mathrm{mL}$ of $\mathrm{Fe})$ was

129 added to a final Fe concentration of $0.1 \mathrm{~g} / \mathrm{L}$. The sample was vigorously stirred with $\mathrm{N}_{2}$ bubbling for 5-10

130 minutes. $10 \% \mathrm{NH}_{3} \cdot \mathrm{H}_{2} \mathrm{O}$ was slowly added to adjust the $\mathrm{pH}$ to 8-9. The sample was kept still for 0.5-1 h,

131 and the supernatant was decanted. The sample slurry was centrifuged at $4000 \mathrm{rpm}$ for 5 minutes and the

132 supernatant was discarded. $20 \mathrm{~mL}$ of conc. $\mathrm{HNO}_{3}$ was added to the residue and the solution was heated at

$133200{ }^{\circ} \mathrm{C}$ until near dryness. The final residue was dissolved with $15 \mathrm{~mL}$ of $3 \mathrm{~mol} / \mathrm{L} \mathrm{HNO}_{3}$ and the solution

134 was loaded onto a 2-mL UTEVA column which was pre-conditioned with $20 \mathrm{~mL}$ of $3 \mathrm{~mol} / \mathrm{L} \mathrm{HNO}$. The

135 UTEVA column was rinsed with $40 \mathrm{~mL}$ of $3 \mathrm{~mol} / \mathrm{L} \mathrm{HNO}_{3}$, followed by $20 \mathrm{~mL}$ of $6 \mathrm{~mol} / \mathrm{L} \mathrm{HCl}$. Uranium

136 absorbed on the column was eluted with $10 \mathrm{~mL}$ of $0.025 \mathrm{~mol} / \mathrm{L} \mathrm{HCl}$. The flow rate for the

137 chromatographic separation was controlled manually to $1.0-1.5 \mathrm{~mL} / \mathrm{min}$. 

measurement of ${ }^{238} \mathrm{U}$ by ICP-MS to calculate the chemical yield of uranium as well as for the calibration of the actual ${ }^{236} \mathrm{U} /{ }^{238} \mathrm{U}$ atomic ratio in the AMS target as described below. To the remaining $\mathrm{U}$ eluate, $3 \mathrm{mg}$

141 of $\mathrm{Fe}$ (as $\mathrm{FeCl}_{3}$ solution) was added, and the sample was adjusted to $\mathrm{pH}>9$ with ammonia to co-

142 precipitate $\mathrm{U}$. The precipitate was dried in an oven at $100{ }^{\circ} \mathrm{C}$ and then was baked in a furnace for $2-3$

143 hours at $700{ }^{\circ} \mathrm{C}$. The sample was then ground to a fine powder, mixed with a similar volume of silver

144 powder and pressed into aluminum sputter target holders for the AMS measurement of ${ }^{236} \mathrm{U} /{ }^{238} \mathrm{U}$. The 145 AMS measurement was carried out at the 3-MV tandem accelerator facility VERA (Vienna 146 Environmental Research Accelerator) at the University of Vienna, Austria. The detailed method for AMS 147 measurement of ${ }^{236} \mathrm{U}$ has been reported elsewhere. ${ }^{31}$

148 The blanks were prepared using the same procedure as the samples for every batch of samples (4 to 8 149 samples), and the actual ${ }^{236} \mathrm{U} /{ }^{238} \mathrm{U}$ atomic ratio (Rs) in the sample was calculated based on the following 150 equation.

$$
R_{s}=\frac{238\left(m_{m} R_{m}-m_{b} R_{b}\right)}{236\left(m_{m}-m_{b}\right)}
$$

Where $m_{m}$ is the ${ }^{238} \mathrm{U}$ mass in the eluate measured by ICP-MS, $R_{m}$ is the ${ }^{236} \mathrm{U} /{ }^{238} \mathrm{U}$ ratio measured in the 153 AMS target, $m_{b}$ is the ${ }^{238} \mathrm{U}$ mass in the eluate of the procedure blank measured by ICP-MS, and $R_{b}$ is the $154{ }^{236} \mathrm{U} /{ }^{238} \mathrm{U}$ ratio measured in the AMS sputter target of the procedure blank.

155 In principle the actual $m_{m}$ and $m_{b}$ should be the corresponding ${ }^{238} \mathrm{U}$ mass in the final sputter sample for 156 AMS instead of the eluate. Due to the large variation of signal intensity (beam current) of ${ }^{238} \mathrm{U}$ in the 157 AMS measurement of the targets without isotopic spike, more accurate ${ }^{238} \mathrm{U}$ values measured by ICP-MS 158 were used to reduce the analytical uncertainty based on the assumption of quantitative U recovery in the 159 sputter target preparation step, which has been confirmed previously. ${ }^{30}$ It should be noted that with the 160 use of pre-purified chemicals, the contributions of ${ }^{236} \mathrm{U}\left(\mathrm{m}_{\mathrm{b}} * \mathrm{Rm}\right)$ and ${ }^{238} \mathrm{U}\left(\mathrm{m}_{\mathrm{b}}\right)$ from procedure blanks are 161 rather negligible compared to their contents in individual samples, ${ }^{30}$ therefore the differences between $\mathrm{R}_{\mathrm{s}}$ 162 and $\mathrm{R}_{\mathrm{m}}$ are within the reported uncertainty ranges (averagely 10\%) for most samples analysed. 


\section{RESULTS AND DISCUSSION}

\section{Distribution of ${ }^{236} U$ concentration and ${ }^{236} U /{ }^{238} U$ ratio in Danish seawater}

165

166

167

168

169

170

171

172

173

174

175

176

177

178

179

180

181

182

The overall results for ${ }^{236} \mathrm{U}$ concentrations and ${ }^{236} \mathrm{U} /{ }^{238} \mathrm{U}$ atomic ratios (as well as salinities, ${ }^{137} \mathrm{Cs}$ and ${ }^{238} \mathrm{U}$ concentrations) obtained in this work are summarized in Table S-1. The geographical distribution patterns of ${ }^{236} \mathrm{U}$ concentrations and ${ }^{236} \mathrm{U} /{ }^{238} \mathrm{U}$ atomic ratios in seawater along the Danish coasts for the 2013 - 2014 are illustrated in Figure 2 and 3, respectively. In general, the ${ }^{236} \mathrm{U}$ concentrations, ${ }^{236} \mathrm{U} /{ }^{238} \mathrm{U}$ atomic ratios as well as salinity obtained in 2013 compare well with the values obtained in 2014 for samples from the same locations, reflecting the relatively slow water exchange rate in the investigated region.

The measured ${ }^{236} U /{ }^{238} \mathrm{U}$ atomic ratios vary within one order of magnitude for both surface water ((9.331.6) $\left.\times 10^{-9}\right)$ and bottom water $\left((5.4-24.9) \times 10^{-9}\right)$ in the period of 2013-2014. In contrast to the distribution pattern of ${ }^{236} U$ concentration, higher ${ }^{236} U /{ }^{238} U$ atomic ratios in both surface and bottom water are observed in the southeast of Zealand, which is dominated by the inflows of the Baltic seawater.

${ }^{236} \mathrm{U}$ concentrations around the coasts of Zealand vary within relatively narrow ranges for both surface $\left((3.6-8.2) \times 10^{7}\right.$ atom/L) and bottom $\left((4.5-8.0) \times 10^{7}\right.$ atom/L) seawater during 2013-2014. Combining the results for seawater from Jutland coasts, it can be seen that there is a decreasing trend of the ${ }^{236} \mathrm{U}$ concentration in the surface seawater from the west coast of Jutland to Kattegat and the Great Belt region. The lowest ${ }^{236} \mathrm{U}$ concentration around Zealand is observed in the surface water of Sundet N (station 11). However, the ${ }^{236} \mathrm{U}$ concentrations increase slightly in the south area (Femern Belt) of Zealand. Among the Jutland surface water, the lowest concentration of ${ }^{236} \mathrm{U}\left(3.2 \times 10^{7}\right.$ atom/L) is observed at Øster Hurup (station 13), which is probably related to the inshore sampling site, where the collected seawater is diluted with fresh water as indicated by its relatively low salinity. In the bottom water around Zealand, lower ${ }^{236} \mathrm{U}$ concentrations are observed along Sundet area (station 10), while relatively higher ${ }^{236} \mathrm{U}$ concentrations are observed for both Kattegat and Femern Belt. The average ${ }^{236} \mathrm{U}$ concentrations in Zealand bottom water $\left(6.1 \times 10^{7}\right.$ atom/L for 2013 and $6.4 \times 10^{7}$ atom/L for 2014$)$ are slightly higher than that in the surface water $\left(5.6 \times 10^{7}\right.$ atom/L for 2013 and $5.7 \times 10^{7}$ atom/L for 2014$)$. 


\section{Dispersion behavior of uranium in North-Baltic Sea mixing region}

189 As indicated by the strongly varying salinity (7.6 to $34.7 \%$ o) and ${ }^{238} \mathrm{U}$ concentration $(0.8-3.9 \mu \mathrm{g} / \mathrm{L})$, the investigated region in this work can be sub-divided into four parts: 1) Jutland coast (North Sea and Skagerrak areas), 2) Northern Zealand (Kattegat area), 3) Western Zealand (Great Belt area) and 4) Southeast Zealand (Southern Baltic Sea area). Compared to surface seawater around Zealand, Jutland surface seawater has the highest levels of salinity and ${ }^{238} \mathrm{U}$ concentrations, which represent for surface water of the North Sea. The lowest salinities and ${ }^{238} \mathrm{U}$ concentrations are observed in the surface of southeast Zealand, which represent for Baltic seawater. Northern Zealand (Kattegat) is a mixing zone of North Sea water and Baltic Sea water. The measured salinities in the bottom water at two locations in the Kattegat are close to the salinity in the open seawater (35\%), two times higher than the surface water in the Kattegat and four times higher than western Baltic seawater. This implies that bottom water in the

199 Kattegat is mainly from the North Sea (North Atlantic Ocean), while the surface water in this area is a 200 mixture of the water from the North Sea and Baltic Sea.

201 The distribution of ${ }^{137} \mathrm{Cs}$ (Figure S-1 and S-2) shows a reversed distribution pattern compared to ${ }^{238} \mathrm{U}$, 202 with highest ${ }^{137}$ Cs activity for both surface and bottom water observed in Southeast Zealand (Møn) and the lowest in the northern Zealand (Hesselø and Kattegat-413). This is attributed to the huge fallout of the 204 Chernobyl accident in the Baltic Sea region, which significantly increased the ${ }^{137}$ Cs concentrations in the 205 Baltic Sea. ${ }^{32}$ Whereas the North Sea and North Atlantic seawater received much less fallout of Chernobyl 206 accident, meanwhile the discharges of ${ }^{137} \mathrm{Cs}$ from the two European reprocessing plants reduced 207 tremendously since the 1980 's. ${ }^{33}$ However, the naturally occurring ${ }^{238} \mathrm{U}$ has much higher concentrations in 208 open seawater (about 3-4 ng/ml) compared to the Baltic Sea $(0.1-2.6 \mathrm{ng} / \mathrm{ml}){ }^{26}$ which has significant fresh 209 water $(<0.5 \mathrm{ng} / \mathrm{ml})$ input from the drainage area. All uranium concentrations obtained in this work $210(\mathrm{~N}=51)$ are plotted versus salinity (Figure 5). A linear regression was performed on the data and the 211 equation is expressed as $U(\mu \mathrm{g} / \mathrm{L})=(0.098 \pm 0.003) \times S+(0.115 \pm 0.077)$ with $R^{2}$ of 0.973 . The 212 slop of this linear regression agrees well with the best-fit line $(U=(0.100 \pm 0.006) \times S-(0.326 \pm$ 
$2130.206, R^{2}=0.78$ ) for worldwide studies in seawater reported previously. ${ }^{34-36}$ The positive linear ${ }^{238} \mathrm{U}$ -

214 salinity relationship might indicate that natural uranium $\left({ }^{238} \mathrm{U}\right)$ in the Baltic Sea mainly originates from

215 seawater introduced from the North Sea and the North Atlantic, its concentration decreases with the

216 increasing dilution by fresh water from riverine inflow to the Baltic Sea. The feed of natural uranium

217 from the catchment through rivers should be very limited compared to the seawater. The positive linear

218 correlation between uranium and salinity might also indicate the relative conservative mixing behavior of

219 uranium during the exchange of the North Sea and Baltic Sea water in the Danish Straits, which is in

220 consistent with precious observations. ${ }^{37}$

$221 \quad{ }^{236} \mathbf{U}$ source terms in Danish Seawater

222 In all samples, the ${ }^{236} \mathrm{U} /{ }^{238} \mathrm{U}$ atomic ratios of (5.4-31.6) $\times 10^{-9}$ are much higher than the theoretically

223 estimated pre-anthropogenic level of $10^{-14}-10^{-10} 3,38$ This indicates seawater analyzed in this work are

224 dominated by anthropogenic ${ }^{236} \mathrm{U}$. There are several possible sources of anthropogenic ${ }^{236} \mathrm{U}:$ 1) global

225 fallout of ${ }^{236} \mathrm{U}$ from nuclear weapons testing; 2) advective transport of ${ }^{236} \mathrm{U}$ from the North Sea originating

226 from discharges of the two major European nuclear reprocessing plants at Sellafield and La Hague; 3)

227 outflows of Baltic seawater carrying ${ }^{236} \mathrm{U}$ from the Chernobyl accident, river run-off and remobilization of

$228 \quad{ }^{236} \mathrm{U}$ from sediment; 4) other local input (e.g., civil and military nuclear reactors).

\section{Global fallout}

230 Large amounts of radionuclides (inducing ${ }^{236} \mathrm{U}$ ) were released during the era of atmospheric nuclear

231 weapons testing in 1952-1963, especially on the Northern Hemisphere. Hence global fallout of ${ }^{236} \mathrm{U}$

232 should undoubtedly be distributed in all the world oceans. Based on measured ${ }^{236} \mathrm{U}$ data from an annually

233 resolved coral core collected in the Caribbean Sea, a total ${ }^{236} \mathrm{U}$ global fallout input of $1060 \mathrm{~kg}$ was

234 estimated via a semi-empirical model. ${ }^{17}$ Based on this number, it has been estimated that a ${ }^{236} \mathrm{U} /{ }^{238} \mathrm{U}$ ratio

235 of about $1 \times 10^{-9}$ is representative for the global fallout signature in modern ocean surface waters. ${ }^{1}$ 
Taking into account the inhomogeneous distribution of global fallout radionuclides, higher ${ }^{236} \mathrm{U} /{ }^{238} \mathrm{U}$

237 ratios than $1 \times 10^{-9}$ should be expected in temperate regions, while lower values should be expected at 238 equator and the Antarctic. Actual ${ }^{236} \mathrm{U} /{ }^{238} \mathrm{U}$ atomic ratios for surface Atlantic Ocean seawater (presumably 239 global fallout is the major source for ${ }^{236} \mathrm{U}$ for this area) have been reported to be $(1.9 \pm 0.6) \times 10^{-9}$ by Eigl 240 et al. ${ }^{21}$ and $0.7 \times 10^{-9}$ by Christl et al. ${ }^{1}$, respectively. Casacuberta et al. ${ }^{20}$ reported ${ }^{236} \mathrm{U} /{ }^{238} \mathrm{U}$ ratios of $(0.9$ $2411.5) \times 10^{-9}$ for North Atlantic seawater $(51.82 \mathrm{~N}, 45.73 \mathrm{~W})$ collected from the similar latitude band as the 242 Danish seawater analyzed in this work (Figure 4).

243 Using a ${ }^{236} \mathrm{U} /{ }^{238} \mathrm{U}$ ratio of $1.0 \times 10^{-9}$ and assuming the ${ }^{238} \mathrm{U}$ concentration in the open ocean is $3.0 \mu \mathrm{g} / \mathrm{L}$, a

$244 \quad{ }^{236} \mathrm{U}$ concentration of $0.8 \times 10^{7}$ atom/L can be estimated as the global fallout level provided no mixing at 245 depth would be taken into account. If a similar concentration of ${ }^{236} \mathrm{U}$ originating from global fallout is 246 applicable to brackish seawater such as Baltic Sea, our ${ }^{236} \mathrm{U}$ concentrations of (3.6-8.2) $\times 10^{7}$ atom/L are 247 4-10 times higher than the estimated global-fallout value. This indicates that direct global fallout from the 248 atmospheric nuclear weapons testing is a minor contribution $(<25 \%)$ to the total ${ }^{236} \mathrm{U}$ inventory in 249 Danish seawater.

\section{Reprocessing plants at Sellafield and La Hague through advective transport}

251 Significant amounts of anthropogenic radionuclides have being discharged from the two European 252 nuclear reprocessing plants since 1952 (Sellafield, UK) and 1966 (La Hague, France), which were 253 transported to the North Sea and further dispersed. So far, the highest ${ }^{236} \mathrm{U} /{ }^{238} \mathrm{U}$ atomic ratio of $(2.8 \pm 0.9)$ $254 \times 10^{-6}$ in seawater was observed in the vicinity of Sellafield in the Irish Sea. ${ }^{7236} \mathrm{U} /{ }^{238} \mathrm{U}$ atomic ratios of 255 (6.4-15.8) $\times 10^{-9}$ have been found in seawater along the eastern coast of Scotland and England reflecting 256 the influence of ${ }^{236} \mathrm{U}$ originating from Sellafield. ${ }^{18} \mathrm{~A}{ }^{236} \mathrm{U} /{ }^{238} \mathrm{U}$ atomic ratio up to $21.6 \times 10^{-9}$ was reported 257 in the vicinity of La Hague and (5.2-11.6) $\times 10^{-9}$ in the central North Sea as well as along the European 258 continental and Norwegian coasts. ${ }^{18}$ 
259 Our results for the ${ }^{236} \mathrm{U} /{ }^{238} \mathrm{U}$ atomic ratios of $(9.3-16.2) \times 10^{-9}$ in seawater collected from the western coast 260 of Jutland are slightly higher than the ratios of $(5.2-11.6) \times 10^{-9}$ reported for the central North Sea, and 261 comparable to the ratios of (8.4-17.7) $\times 10^{-9}$ for the European continental coastal areas of the North Sea in 262 2009. ${ }^{18,19}$ This might be due to the fact that contaminated water from La Hague (as well as that from

263 Sellafield) moves northward along the European continental coast, ${ }^{39,40}$ and therefore the ${ }^{236} \mathrm{U}$

264 concentrations in the central North Sea are lower than those from coastal areas. Nevertheless, the general 265 concentrations of ${ }^{236} \mathrm{U}$ in Danish seawater are at the same magnitude as the North Sea water, and 10-100 266 times higher compared to other open oceans including the Atlantic, the Japan Sea (after the Fukushima 267 accident) and the Pacific that were mostly affected by ${ }^{236} \mathrm{U}$ input from global fallout. ${ }^{1,16,20,22,41,42}$ it should 268 be noted that, ${ }^{236} \mathrm{U}$ concentrations in saline Kattegat bottom seawater (stations 3 and 12 ) are nearly two 269 times higher than those in low salinity surface water. The notably elevated ${ }^{236} \mathrm{U}$ level in Danish seawater 270 and the ${ }^{236} \mathrm{U}$ difference between surface and bottom water in Kattegat suggests the ${ }^{236} \mathrm{U}$ input to Danish 271 seawater from the North Sea originating from the two European reprocessing plants.

272 However, at first glance it appears unexpectedly that the difference in ${ }^{236} \mathrm{U}$ concentrations between surface 273 and bottom seawater in Kattegat is much smaller compared to other anthropogenic radionuclides, e.g., ${ }^{129} \mathrm{I}$ 274 concentrations in bottom seawater are 1-2 orders of magnitude higher than in surface seawater in this 275 region in $2007 .{ }^{43}$ This might be explained by the facts that 1) ${ }^{236} \mathrm{U}$ release histories from the two nuclear 276 reprocessing plants are significantly different from those of ${ }^{129} \mathrm{I}$. Release of ${ }^{129} \mathrm{I}$ from the two reprocessing 277 plants have increased since the 1990's and reached a maximum around 2000, while releases of ${ }^{236} \mathrm{U}$ as 278 well as other actinides have declined significantly since the 1990's, which is attributed to the 279 implementation of an actinide removal processes in the reprocessing plants. Therefore, most of the ${ }^{236} \mathrm{U}$ in 280 European seawater should originate from early releases before the 1990’s, especially during the 1970's 281 and 1980’s. 2) The ${ }^{129}$ I discharges from the two European reprocessing plants account for more than 95\% 282 of ${ }^{129} \mathrm{I}$ in the environment, which are two orders of magnitude higher than the entire releases from 283 atmospheric nuclear weapons testing. While the total inventory of ${ }^{236} \mathrm{U}$ released from the two European 
reprocessing plants has been estimated in the range of 115 to $250 \mathrm{~kg},{ }^{20}$ which is less than one fourth of the estimated input from global fallout of atmospheric nuclear weapons testing.

\section{Advective transport of ${ }^{236} U$ via outflow from the Baltic Sea}

287 It has been reported that more than $95 \%$ of ${ }^{129} \mathrm{I}$ in the Baltic Sea originates from European reprocessing

288 facilities, especially from La Hague. ${ }^{44}$ More than $30 \%$ of ${ }^{129}$ I in the south Baltic and $>93 \%$ in the

289 Kattegat originates from marine discharges and is transported by marine currents. Being similarly

290 conservative as ${ }^{129} \mathrm{I},{ }^{236} \mathrm{U}$ should also be transported through the Kattegat into the South Baltic. However,

291 the ${ }^{236} \mathrm{U}$ concentrations in seawater from south of Zealand are slightly lower but still at the same level as

292 those from Kattegat. For example, in the samples collected at Møn in the Baltic Sea, as high as (4.7-5.7) ×

$29310^{7}$ atom/L of ${ }^{236} \mathrm{U}$ were measured during 2013-2014, which is about two times higher than the ${ }^{236} \mathrm{U}$

294 concentrations in the Black Sea water and Danube river which feeds into Black Sea. ${ }^{21,45}$

295 It can be seen from Figure 6 that ${ }^{236} \mathrm{U}$ concentrations observed in this work for Danish seawater are fairly

296 independent of salinity, while the ${ }^{236} \mathrm{U} /{ }^{238} \mathrm{U}$ ratios increase with the decreasing salinity which results in

297 even higher ${ }^{236} \mathrm{U} /{ }^{238} \mathrm{U}$ atomic ratios in the low salinity Baltic Sea samples than in the North Sea region.

298 This unexpected high level ${ }^{236} \mathrm{U}$ in the Baltic Sea area and relatively homogenous distribution of ${ }^{236} \mathrm{U}$

299 along the Danish coasts suggest that, an unknown source of ${ }^{236} U$ might exist in the Baltic Sea, which

300 contributes with a similar magnitude as those presently from Sellafield and La Hague. Consequently,

301 special consideration must be given to clarify possible source terms in the Baltic Sea, when applying ${ }^{236} \mathrm{U}$

302 as an oceanographic tracer in the North Atlantic-Arctic Ocean.

303 A simple binary mixing model was applied to shed some light on the source terms in the Baltic Sea. The

304 variations of ${ }^{236} \mathrm{U} /{ }^{238} \mathrm{U}$ atomic ratio and ${ }^{236} \mathrm{U}$ concentration with the salinity were simulated in this model

305 assuming there were two major endpoint sources of ${ }^{236} \mathrm{U}$ in the investigated region. One endpoint source

306 of ${ }^{236} \mathrm{U}$ was the high salinity North Sea water carrying high reprocessing ${ }^{236} \mathrm{U}$ (salinity=35\%, ${ }^{238} \mathrm{U}=3.3$

$307 \mathrm{ug} / \mathrm{L}$ and ${ }^{236} \mathrm{U}=8 \times 10^{7}$ atom/L), while the other endpoint source was the fresh Baltic Sea water carrying 
unknown source of ${ }^{236} \mathrm{U}\left({ }^{238} \mathrm{U}=0.2 \mathrm{ug} / \mathrm{l},{ }^{236} \mathrm{U}=3 \times 10^{7}\right.$ atom/L, ${ }^{236} \mathrm{U} /{ }^{238} \mathrm{U}$ atomic ratio is about $1.2 \times 10^{-9}$ and salinity $=2 \%$ ). Interestingly, the simulated variations of ${ }^{236} U /{ }^{238} U$ vs. salinity and ${ }^{236} U$ concentration vs. salinity (Figure 6) are in good agreement with the measurement data in this work. This confirms that besides the reprocessing input, a source from the Baltic Sea also contributes to ${ }^{236} \mathrm{U}$ in the investigated region. ${ }^{236} \mathrm{U}$ in the Baltic Sea might originate from a number of inputs as discussed below.

\section{Chernobyl accident}

It is well know that the Chernobyl accident has caused high deposition of radionuclides in the Baltic Sea and the catchment areas. Our ${ }^{137} \mathrm{Cs}$ results show that the average ${ }^{137} \mathrm{Cs}$ activity is much higher in surface water $\left(25 \mathrm{~Bq} / \mathrm{m}^{3}\right)$ than in bottom water $\left(9 \mathrm{~Bq} / \mathrm{m}^{3}\right)$ and the overall ${ }^{137} \mathrm{Cs}$ activity in Danish seawater has a negative linear correlation $\left(\mathrm{R}^{2}=0.984\right)$ with salinity. This indicates seawater transport of the Chernobylderived ${ }^{137}$ Cs through the Danish Straits from the Baltic Sea to the North Sea and in the opposite direction for lower level ${ }^{137}$ Cs from the North Sea to the Baltic.

${ }^{236} \mathrm{U} /{ }^{238} \mathrm{U}$ atomic ratios of $10^{-6}-10^{-3}$ have been measured in soils contaminated with fuel debris in the close vicinity of the Chernobyl power plant. At a site up to a distance of $200 \mathrm{~km}$ from the Chernobyl, ${ }^{236} \mathrm{U} /{ }^{238} \mathrm{U}$ atomic ratios were found to be $(2-4) \times 10^{-7} .{ }^{3}$ So far, little is known about the Chernobyl

323 deposition of ${ }^{236} \mathrm{U}$ into the Baltic Sea. However, only minor Chernobyl input of other actinides was 324 observed in the Baltic Sea and the surrounding areas. ${ }^{46-48}$ It is therefore reasonable to predict that the atmospheric dispersion of ${ }^{236} \mathrm{U}$ into the Baltic Sea may not be of significance either, since uranium is no a volatile element and the Chernobyl accident occured 500-600 km away from the Baltic Sea.

\section{Input of global fallout ${ }^{236} \mathrm{U}$ in Baltic Sea through direct deposition}

The Baltic Sea is a rather shallow (50-60 m on average) brackish regional sea. ${ }^{26,49-51}$ As a consequence,

329 the distribution depth of ${ }^{236} \mathrm{U}$ is restrained within ca. $60 \mathrm{~m}$, compared to open oceans where ${ }^{236} \mathrm{U}$

330 penetrated into hundreds or even thousands meters depth, higher ${ }^{236} \mathrm{U}$ concentrations in the Baltic Sea 331 introduced by global fallout could be expected. 
332 The areal deposition of global fallout ${ }^{236} \mathrm{U}$ has been estimated to be $17.8 \times 10^{12}$ atoms $/ \mathrm{m}^{2}$ based on the 333 analysis of soil samples in Japan. ${ }^{52}$ Several studies on ${ }^{236} \mathrm{U}$ inventories in different marine water columns 334 have obtained values ranging within $(7.7-47) \times 10^{12}$ atom $/ \mathrm{m}^{2} \cdot{ }^{16,20,22,42,53}$ Taking $17.8 \times 10^{12}$ atom $/ \mathrm{m}^{2}$ as 335 the global fallout deposition of ${ }^{236} \mathrm{U}$ into the Baltic Sea, the surface area of $451000 \mathrm{~km}^{2}$ and the volume of $33622000 \mathrm{~km}^{3}$, the ${ }^{236} \mathrm{U}$ concentration in the Baltic Sea should have reached $36.5 \times 10^{7}$ atom/L in the 1950 -

337 1960s. Since the average residence time of Baltic Sea water is estimated to be 30-35 years (half exchange 338 time of about 20-25 years), ${ }^{54,55}$ after 60 years (the two times of residence time) the global-fallout derived $339{ }^{236} \mathrm{U}$ in modern Baltic Sea water would be reduced to about $(1 / \mathrm{e})^{-2}=13.5 \%$, i.e. $4.9 \times 10^{7}$ atom/L. This 340 value agrees well with those obtained in this work for seawaters collected close to Baltic Sea area, and 341 possibly support the notion of persisting influence of global fallout in the Baltic Sea. However, we do not 342 want to overemphasize this simple estimation.

\section{Input of global fallout ${ }^{236} \mathrm{U}$ in Baltic Sea through river runoff}

344 There are many rivers around the Baltic Sea, which drain $1720000 \mathrm{~km}^{2}$ and discharge about $480 \mathrm{~km}^{3} / \mathrm{y}^{51}$

345 The fresh water inflow through river run-off has high impact on the Baltic Sea environment. It has been

346 reported that the fresh water carries a significant amount of pollutant including anthropogenic

347 radionuclides into the Baltic Sea. ${ }^{51}$ Unlike ${ }^{238} \mathrm{U}$ which mainly exists inside the mineral phase of soil, 348 global fallout ${ }^{236} \mathrm{U}$ is expected to be dissolved or loosely adsorbed on the surface of soil grains. Therefore, $349 \quad{ }^{236} \mathrm{U}$ can be easily leached out or flushed by precipitation and transported by river run-off.

350 Relatively high ${ }^{236} \mathrm{U}$ concentrations in fresh water have been reported by several studies, for example, a 351 wide range of ${ }^{236} \mathrm{U}$ concentrations from $4.14 \times 10^{6}$ to $2.14 \times 10^{9}$ atom/L have been reported in water 352 samples from wells and rivers in Austria. ${ }^{45}$ The contribution of global fallout ${ }^{236} \mathrm{U}$ deposited in the 353 catchment area of the rivers draining into the Baltic Sea might be another major source of ${ }^{236} \mathrm{U}$. Glacier 354 melt water would be especially suspicious to release stored ${ }^{236} \mathrm{U}$ from global fallout (up to $10^{-4}$ of 

data from the North Atlantic and the Arctic Ocean.

\section{Potential resuspension of the reprocessing derived ${ }^{236} U$ deposited in the Baltic Sea}

358 Another possible source of high ${ }^{236} \mathrm{U}$ levels in the Baltic Sea might be ${ }^{236} \mathrm{U}$ from the peak discharge era 359 from the reprocessing plants from 1970-1990, which has been transported into and then retained in Baltic

Sea water or sediment. It has been reported that the transport of the water mass from La Hague to Hesselø takes about 1.5 year $^{44}$, while the turnaround time for Baltic Sea water is estimated to be $30-35$ years, ${ }^{54,55}$ Therefore, the recent in-flow of saline water from the North Sea carries the signature of relatively low ${ }^{236} \mathrm{U} /{ }^{238} \mathrm{U}$ atomic ratios would in line with the presently low reprocessing releases of ${ }^{236} \mathrm{U}$. Whereas the older and more saline water retained in the Baltic main basin may still preserve the higher ${ }^{236} U /{ }^{238} U$ ratios of the North Sea water from 1970 - 1990. Coincidently, the dilution of this saline water in Baltic Sea with fresh water has led to a ${ }^{236} \mathrm{U}$ concentration independent of salinity. Such a dilution by fresh water (without ${ }^{236} U$ and ${ }^{238} U$ ) would not affect the isotopic ratio ${ }^{236} U /{ }^{238} U$ (compare Figure $6 b$ ).

Sediments constitute another way of storing ${ }^{236} \mathrm{U}$. The local marine environment in the Baltic Sea is significantly different from the open seas. Most uranium of in the open seawater (90\%) exists as U(VI) carbonate complexes. The Baltic Sea water has lower $\mathrm{pH}(<7)$ compared to open seawater $(\mathrm{pH}=8-9)$. With the depletion of oxygen and even presence of $\mathrm{H}_{2} \mathrm{~S}$ in deep layers of the central area of the Baltic Proper, the U(VI) maybe reduced and then scavenged by organic particles or collides, etc., deposited into sediment, and later be remobilized. It has been reported that natural uranium is enriched in organic-rich mud from the Gotland Deep in the Baltic Sea with uranium concentration up to10 ppm. ${ }^{27}$. Experimental data have indicated that in Baltic Sea mud, the uranium sorbed by soluble organic matter derived from land and by settling of partly decomposed plankton constitutes about one-half of uranium in mud. ${ }^{27}$ Provided reprocessing derived ${ }^{236} \mathrm{U}$ has a similar environmental behavior as natural uranium, high discharges in the 1970's and 1980's might have been transported to Baltic Sea and deposited in the 
sediment. With the dynamic of oxygenated water irregularly flowing into the Baltic Sea, the remobilization of ${ }^{236} \mathrm{U}$ from the sediment might be elevated. However, as per the general conservative

381 behavior based on our results mentioned before and literature report, ${ }^{37}$ the enrichment of uranium in

382 Baltic sediment might only occur in some anoxic basins (e.g., Gotland Basin). Besides, the remobilization

383 of uranium from sediment depends on the time span of oxygenate conditions in the bottom water. For a

384 short time period with ${ }^{236} \mathrm{U}$ mainly in the surface sediments, the remobilized uranium could very well

385 show enhanced ${ }^{236} \mathrm{U} /{ }^{238} \mathrm{U}$ ratio, but for longer time spans with continuous integration of natural ${ }^{238} \mathrm{U}$ into

386 sediment, it becomes more likely that the remobilized uranium would be diluted to have a lower ${ }^{236} \mathrm{U} /{ }^{238} \mathrm{U}$

387 ratio. Nevertheless, to make the picture more objective, ${ }^{236} \mathrm{U}$ profiles in Baltic water columns and

388 sediment cores, especially from the long-term anoxic basin of Baltic Sea would be useful.

If the early reprocessing derived ${ }^{236} \mathrm{U}$ stored in Baltic sediments is a major input of ${ }^{236} \mathrm{U}$ into the North 390 Sea, this might affect tracer applications of ${ }^{236} \mathrm{U}$ in the North Atlantic-Arctic Ocean. Regardless of the 391 extra ${ }^{236} \mathrm{U}$ source in the Baltic Sea, the seemingly enriched ratios may have to be considered when using

$392{ }^{236} \mathrm{U}$ as a tracer. On the other hand, ${ }^{236} \mathrm{U}$ adds to the suit of available geochemical and oceanic tracers that 393 could find use in studies of water exchange, interaction between sediment and water in the Baltic Sea as 394 well as its relationship to the changes of the ecosystem, water condition and the climate in the Baltic Sea 395 Local input of ${ }^{236} \mathbf{U}$ in Danish seawater

396 Two Swedish nuclear power plants at Barsebäck and Ringhals may discharge radionuclides into Danish 397 Straits and the Finnish (Lovisa, Olkiluoto and Hanhikivi) and Swedish (Frosmark and Oskarshamn) 398 nuclear reactors may add to the ${ }^{236} \mathrm{U}$ inventory inside the Baltic Sea, but historical records for uranium 399 isotope discharges are not available from these nuclear plants. ${ }^{57}$ However, to the best of our knowledge, 400 no significant levels of radionuclides have been detected in the surrounding environment of these two 401 power plants. Thus, it can be assumed that the contribution of ${ }^{236} \mathrm{U}$ from these local nuclear reactors to 402 Danish seawater might be negligible. During 1950-1990, three nuclear research reactors were built and 403 operated at Risø, Denamrk. ${ }^{58,59}$ To evaluate the local input of ${ }^{236} U$ from the Danish reactors, several 

seawater samples were collected in Roskilde Fjord including the discharge point of Risø reactor (DR3).

405 The ${ }^{236} \mathrm{U}$ levels in all collected seawaters are comparable to those obtained for Zealand seawater (Table S-

406 1), indicating no significant contributions from the nuclear reactors at Risø.

407 ASSOCIATED CONTENT

408 Supporting Information

409 Supporting Information summarizes the overall results of ${ }^{236} U$ and ${ }^{236} U / 238 U$ for Danish seawater in 2013

410 and 2014, and illustrates the distribution of ${ }^{238} \mathrm{U}$ and ${ }^{137} \mathrm{Cs}$ concentrations in seawater along the Danish

411 coasts, respectively. This material is available free of charge via the Internet at http://pubs.acs.org.

\section{AUTHOR INFORMATION}

\section{Corresponding Author}

414 *Phone: +45 46775367. E-mail: jiqi@dtu.dk.

\section{$415 \quad$ Notes}

416 The authors declare no competing financial interest.

\section{ACKNOWLEDGEMENT}

418 J. Qiao is grateful to support from colleagues in the Radioecology Section, Center for Nuclear 419 Technologies, Technical University of Denmark. The authors are thankful to the constructive comments 420 and input from Dr. Marcus Christl (Laboratory of Ion Beam Physics, ETH-Zurich) to the binary mixing 421 model for discussing the source term of ${ }^{236} \mathrm{U}$ in the Baltic Sea. The authors also wish to thank the 422 Environmental Protection Agency, Danish Ministry of the Environment, for financial support, and the 423 Danish Navy collecting seawater samples. 


\section{REFERENCES}

426

427

428

429

430

431

432

433

434

435

436

(1) Christl, M.; Lachner, J.; Vockenhuber, C.; Lechtenfeld, O.; Stimac, I.; van der Loeff, M. R.; Synal, H.-A. A depth profile of uranium-236 in the Atlantic Ocean. Geochim. Cosmochim. Acta 2012, 77, 98-107.

(2) Sakaguchi, A.; Kawai, K.; Steier, P.; Quinto, F.; Mino, K.; Tomita, J.; Hoshi, M.; Whitehead, N.; Yamamoto, M. First results on 236U levels in global fallout. Sci. Total Environ. 2009, 407 (14), $4238-4242$.

(3) Steier, P.; Bichler, M.; Keith Fifield, L.; Golser, R.; Kutschera, W.; Priller, A.; Quinto, F.; Richter, S.; Srncik, M.; Terrasi, P.; et al. Natural and anthropogenic 236U in environmental samples. Nucl. Inst.and Methods Phys. Res. B 2008, 266 (10), 2246-2250.

(4) Hotchkis, M. A. C.; Child, D.; Fink, D.; Jacobsen, G. E.; Lee, P. J.; Mino, N.; Smith, A. M.; Tuniz, C. Measurement of $236 \mathrm{U}$ in environmental media. Nucl. Instruments Methods Phys Res - Sect. B Only - Beam Interact Mater Atoms 2000, 172.

(5) Desideri, D.; Meli, M. a; Roselli, C.; Testa, C.; Boulyga, S. F.; Becker, J. S. Determination of 236U and transuranium elements in depleted uranium ammunition by alpha-spectrometry and ICPMS. Anal. Bioanal. Chem. 2002, 374 (6), 1091-1095.

(6) Purser, K. H.; Kilius, L. R.; Litherland, A. E.; Zhao, X. Detection of 236U: a possible 100-million year neutron flux integrator. Nucl. Instruments Methods Phys. Res. Sect. B Beam Interact. with Mater. Atoms 1996, 113 (1-4), 445-452.

(7) Lee, S. H.; Povinec, P. P.; Wyse, E.; Hotchkis, M. A. C. Ultra-low-level determination of 236U in IAEA marine reference materials by ICPMS and AMS. Appl. Radiat. Isot. 2008, 66 (6-7), 823828. 
447

(8) Quinto, F.; Steier, P.; Wallner, G.; Wallner, A.; Srncik, M.; Bichler, M.; Kutschera, W.; Terrasi, F.; Petraglia, A.; Sabbarese, C. The first use of $236 \mathrm{U}$ in the general environment and near a shutdown nuclear power plant. Appl. Radiat. Isot. 2009, 67 (10), 1775-1780.

(9) Boulyga, S. F.; Matusevich, J. L.; Mironov, V. P.; Kudrjashov, V. P.; Halicz, L.; Segal, I.; McLean, J. A.; Montaser, A.; Sabine Becker, J. Determination of 236U/238U isotope ratio in contaminated environmental samples using different ICP-MS instruments. J. Anal. At. Spectrom. 2002, 17 (8), 958-964.

(10) Bellucci, J. J.; Simonetti, A.; Wallace, C.; Koeman, E. C.; Burns, P. C. Isotopic Fingerprinting of the World’s First Nuclear Device Using Post-Detonation Materials. Anal. Chem. 2013, 85 (8), 4195-4198.

(11) Wendel, C. C.; Oughton, D. H.; Lind, O. C.; Skipperud, L.; Fifield, L. K.; Isaksson, E.; Tims, S. G.; Salbu, B. Chronology of Pu isotopes and 236U in an Arctic ice core. Sci. Total Environ. 2013, 461-462, 734-741.

(12) Parrish, R.; Thirlwall, M.; Pickford, C.; Horstwood, M.; Gerdes, A.; Anderson, J.; Coggon, D. Determinaiton of 238U/235U, 236U/238U and uramium concentraiton in urine using SF-ICP-MS and MC-ICP-MS: na interlaboratory comparison. Health Phys. 2006, 90 (2), 127-138.

(13) Al-qasmi, H.; Law, G. T. W.; Fi, L. K.; Livens, F. R. Origin of artificial radionuclides in soil and sediment from North Wales. J. Environ. Radioact. 2016, 151, 244-249.

(14) Yang, G.; Tazoe, H.; Yamada, M. Analytica Chimica Acta Determination of 236U in environmental samples by single extraction chromatography coupled to triple-quadrupole inductively coupled plasma-mass spectrometry. Anal. Chim. Acta 2016, 944, 44-50.

(15) Chamizo, E.; Jimenez-Ramos, M.; Wacker, L.; Vioque, I.; Calleja, A.; Garcia-Leon, M.; GarciaTenorio, R. Isolation of Pu-isotopes from environmental samples using ion chromatography for 
accelerator mass spectrometry and alpha spectrometry. Anal. Chim. Acta 2008, 606 (2), 239-245.

471

472

473

474

475

476

477

478

479

480

481

482

483

484

485

486

487

488

489

490

491

(16) Sakaguchi, A.; Kadokura, A.; Steier, P.; Takahashi, Y.; Shizuma, K.; Hoshi, M.; Nakakuki, T.; Yamamoto, M. Uranium-236 as a new oceanic tracer: A first depth profile in the Japan Sea and comparison with caesium-137. Earth Planet. Sci. Lett. 2012, 333, 165-170.

(17) Winkler, S. R.; Steier, P.; Carilli, J. Bomb fall-out 236U as a global oceanic tracer using an annually resolved coral core. Earth Planet. Sci. Lett. 2012, 359-360, 124-130.

(18) Christl, M.; Lachner, J.; Vockenhuber, C.; Goroncy, I.; Herrmann, J. J.; Synal, H.-A. First data of Uranium-236 in the North Sea. Nucl. Instr. Meth. B 2013, 294, 530-536.

(19) Christl, M.; Casacuberta, N.; Lachner, J.; Maxeiner, S.; Vockenhuber, C.; Synal, H.-A.; Goroncy, I.; Herrmann, J. J.; Daraoui, A.; Walther, C.; et al. Status of 236U analyses at ETH Zurich and the distribution of $236 \mathrm{U}$ and $129 \mathrm{I}$ in the North Sea in 2009. Nucl. Instr. Meth. B 2015, 361, 510-516.

(20) Casacuberta, N.; Christl, M.; Lachner, J.; van der Loeff, M. R.; Masqué, P.; Synal, H. a. A first transect of 236U in the North Atlantic Ocean. Geochim. Cosmochim. Acta 2014, 133, 34-46.

(21) Eigl, R.; Srncik, M.; Steier, P.; Wallner, G. 236U/238U and 240Pu/239Pu isotopic ratios in small (2 L) sea and river water samples. J. Environ. Radioact. 2013, 116, 54-58.

(22) Casacuberta, N.; Masqué, P.; Henderson, G.; Rutgers van-der-Loeff, M.; Bauch, D.; Vockenhuber, C.; Daraoui, A.; Walther, C.; Synal, H. A.; Christl, M. First 236U data from the Arctic Ocean and use of 236U/238U and 129I/236U as a new dual tracer. Earth Planet. Sci. Lett. 2016, 440.

(23) Marcus, C.; Nuria, C.; Christof, V.; Christoph, E.; Pascal, B. du B.; Jurgen, H.; Synal, H.-A. Reconstruction of the 236U imput function for the Northest Atlantic Ocean: Implications for 129I/236U and 236U/238-based tracer ages. J. Geophys. Res. Ocean. 2016, 120, 7282-7299.

(24) KU, T. L.; Knauss, K. G.; Mathieu, G. G. Uranium in open ocean - concentration and isotopic 
composition. Deep. Res. 1977, 24 (11), 1005-1017.

493

494

495

496

497

498

499

500

501

502

503

504

505

506

507

508

509

510

511

512

513

(25) Klinkhammer, G. .; Palmer, M. . Uranium in the oceans: Where it goes and why. Geochim. Cosmochim. Acta 1991, 55 (7), 1799-1806.

(26) Lofvendahl, R. Dissolved uranium in the Baltic Sea. Mar. Chem. 1987, 21 (3), 213-227.

(27) Swanson, V. E. Geology and geochemistry of uranium in marine black shales: a review. USGS Prof. Pap. 1961, 365 (C), 50pp.

(28) Anderson, R. F.; Fleisher, M. Q.; LeHuray, A. P. Concentration, oxidation state, and particulate flux of uranium in the Black Sea. Geochim. Cosmochim. Acta 1989, 53 (9), 2215-2224.

(29) Qiao, J.; Hou, X.; Roos, P.; Miró, M. Rapid and simultaneous determination of neptunium and plutonium isotopes in environmental samples by extraction chromatography using sequential injection analysis and ICP-MS. J. Anal. At. Spectrom. 2010, 25 (11), 1769.

(30) Qiao, J.; Hou, X.; Steier, P.; Nielsen, S.; Golser, R. Method for 236U Determination in Seawater Using Flow Injection Extraction Chromatography and Accelerator Mass Spectrometry. Anal. Chem. 2015, 87 (14), 7411-7417.

(31) Steier, P.; Dellinger, F.; Forstner, O.; Golser, R.; Knie, K.; Kutschera, W.; Priller, A.; Quinto, F.; Srncik, M.; Terrasi, F.; et al. Analysis and application of heavy isotopes in the environment. Nucl. Inst.and Methods Phys. Res. B 2010, 268 (7-8), 1045-1049.

(32) IAEA. Environmental Consequences of the Chernobyl Accident and their Remediation:Twenty Years of Experience. Int. At. Energy Agency,Radiological Assess. Rep. Ser. 2006, STI/PUB/12, 196.

(33) Povinec, P. P.; Bailly du Bois, P.; Kershaw, P. J.; Nies, H.; Scotto, P. Temporal and spatial trends in the distribution of 137Cs in surface waters of Northern European Seas—a record of 40 years of 
investigations. Deep Sea Res. Part II Top. Stud. Oceanogr. 2003, 50 (17-21), 2785-2801.

515

516

517

518

519

520

521

522

523

524

525

526

527

528

529

530

531

532

533

534

535

(34) Chen, J. H.; Lawrence Edwards, R.; Wasserburg, G. J. 238U,234U and232Th in seawater. Earth Planet. Sci. Lett. 1986, 80 (3-4), 241-251.

(35) Owens, S. A.; Buesseler, K. O.; Sims, K. W. W. Re-evaluating the U-238-salinity relationship in seawater: Implications for the U-238-Th-234 disequilibrium method. Mar. Chem. 2011, 127 (1-4), 31-39.

(36) Pates, J. M.; Muir, G. K. P. U - salinity relationships in the Mediterranean : Implications for Th : 238 U particle flux studies. Mar. Chem. 2007, 106, 530-545.

(37) Andersson, P. S.; Wasserburg, G. J.; Chen, J. H.; Papanastassiou, D. A.; Ingri, J. 238U-234U and 232Th-230Th in the Baltic Sea and in river water. Earth Planet. Sci. Lett. 1995, 130, 217-234.

(38) Zhao, X.-L.; Nadeau, M.-J.; Kilius, L. R.; Litherland, A. E. The first detection of naturallyoccurring 236U with accelerator mass spectrometry. Nucl. Instruments Methods Phys. Res. Sect. B Beam Interact. with Mater. Atoms 1994, 92 (1-4), 249-253.

(39) Orre, S.; Gao, Y.; Drange, H.; Nilsen, J. E. O. A reassessment of the dispersion properties of Tc-99 in the North Sea and the Norwegian Sea. J. Mar. Syst. 2007, 68, 24-38.

(40) Alfimov, V.; Aldahan, a.; Possnert, G.; Kekli, a.; Meili, M. Concentrations of 129I along a transect from the North Atlantic to the Baltic Sea. Nucl. Instr. Meth. Phys. Res. B 2004, 223-224 (SPEC. ISS.), 446-450.

(41) Sakaguchi, A.; Nomura, T.; Steier, P.; Gloser, R.; Sasaki, K.; Watanabe, T.; Nakakuki, T.; Takahashi, Y.; Yamano, H. Temporal and vertical distributions of anthropogenic 236U in the Japan Sea using a coral core and seawater samples. J. Geophys. Res. Ocean. 2016, 121 (1), 4-13.

(42) Eigl, R.; Steier, P.; Winkler, S. R.; Sakata, K.; Sakaguchi, A. First study on 236U in the Northeast 
Pacific Ocean using a new target preparation procedure for AMS measurements. J. Environ. Radioact. 2016, 162, 244-250.

(43) Hou, X. L.; Aldahan, A.; Nislen, S.; Possnert, G.; Nies, H.; Hedfords, J. Speciation of 129I and 127I in seawater and implications for sources and transport pathways in North Sea. Environ. Sci. Technol. 2007, 41, 5993-5999.

(44) Hou, X. Application of 129 I as an environmental tracer. J. Radioanal. Nucl. Chem. 2004, 262 (1), $67-75$.

(45) Srncik, M.; Steier, P.; Wallner, G. Determination of the isotopic ratio 236U/238U in Austrian water samples. Nucl. Inst.and Methods Phys. Res. B 2010, 268 (7-8), 1146-1149.

(46) Struminska-Parulska, D.; Skwarzec, B. Plutonium isotopes $238 \mathrm{Pu}, 239+240 \mathrm{Pu}, 241 \mathrm{Pu}$ and 240 $\mathrm{Pu} / 239 \mathrm{Pu}$ atomic ratios in the southern Baltic Sea ecosystem. Oceanologia 2010, 52 (April 1986), 499-512.

(47) Lindahl, P.; Roos, P.; Holm, E.; Dahlgaard, H. Studies of Np and Pu in the marine environment of Swedish-Danish waters and the North Atlantic Ocean. J. Environ. Radioact. 2005, 82 (3), 285301.

(48) Holm, E. Plutonium in the Baltic Sea. Radiat, Appl Vol, Isot 1995, 46 (11), 1225-1229.

(49) Baltic environment No . 61 radioactivity in the Baltic Sea 1984 - 1991 Helsinki Commision Baltic Marine Environment Protection Commission. 1995, No. 61.

(50) Kullenberg, G.; Jacobsen, T. S. The Baltic Sea: an Outline of its Physical Oceanography. Mar. Pollut. Bull. 1981, 12 (6), 183-186.

(51) Rodhe, J.; Tett, P.; WUFF, F. The Baltic and North Seas: a regional review of some important physical-chemical-biological interaction processes (20, S). In The Sea; Robinson, R. A., Brink, H. 
K., Eds.; President and Fellows of Harvard College, 2004; Vol. 14, pp 1029-1072.

559

560

561

562

563

564

565

566

567

568

569

570

571

572

573

574

575

576

577

578

(52) Sakaguchi, A.; Kawai, K.; Steier, P.; Imanaka, T.; Hoshi, M.; Endo, S.; Zhumadilov, K.; Yamamoto, M. Feasibility of using $236 \mathrm{U}$ to reconstruct close-in fallout deposition from the Hiroshima atomic bomb. Sci. Total Environ. 2010, 408 (22).

(53) A.Sakaguchi; M.Yamamoto; M.Hoshi; K.N.Apsalikov; B.I.Gusev. No Title. J.Radioanal.Nucl.Chem. 2004, 260, 543-555.

(54) Winsor, P.; Rodhe, J.; Omstedt, A. Baltic Sea Ocean Climate : An Analysis of 100 Yr of Hydrographic Data with Focus on the Freshwater Budget Baltic Sea ocean climate: an analysis of $100 \mathrm{yr}$ of hydrographic data with focus on the freshwater budget. Clim. Res. 2001, 18, 5-15.

(55) Rodhe, B. J.; Winsor, P. On the influence of the freshwater supply on the Baltic Sea mean salinity. Tellus 2002, 54A, 175-186.

(56) Wendel, C. C.; Oughton, D. H.; Lind, O. C.; Skipperud, L.; Fifield, L. K.; Isaksson, E.; Tims, S. G.; Salbu, B. Chronology of Pu isotopes and U-236 in an Arctic ice core. Sci. Total Environ. 2013, 461, 734-741.

(57) Plants, N. P. Liquid Discharges from the Ringhals and Barsebdck Nuclear Power Plants.

(58) Data, G.; Treaty, E. General Data as called for under Article 37 of the Euratom Treaty Decommissioning of the Nuclear Facilities at Risø National Laboratory , Denmark disposal of radioactive waste required under Article Submission by Risø National Laboratory and the National; 2003.

(59) Liquid discharges from nuclear installations , 2011 Radioactive Substances Series. 2011. 


\section{$579 \quad$ FIGURE CAPTIONS}

580 Figure 1. Sampling stations in this work.

581 Figure 2. Distribution of ${ }^{236} U$ concentration (atom/L) in seawater along the Danish coasts in 2013 and $582 \quad 2014$

583 Figure 3. Distribution of ${ }^{236} \mathrm{U} /{ }^{238} \mathrm{U}$ atomic ratio in seawater along the Danish coasts in 2013 and 2014

584 Figure 4. Comparison of ${ }^{236} \mathrm{U} /{ }^{238} \mathrm{U}$ atomic ratios in water samples from different locations

$585 \quad$ Figure 5. Correlation ${ }^{238} \mathrm{U}$ and ${ }^{137} \mathrm{Cs}$ concentrations with salinity

586 Figure 6. Variation of ${ }^{236} \mathrm{U}$ concentrations and ${ }^{236} \mathrm{U} /{ }^{238} \mathrm{U}$ atomic ratios with salinity 
Figure 1. Overview of schematic circulation water mass in North Sea-Baltic Sea region and sampling stations in this work (ECW: English

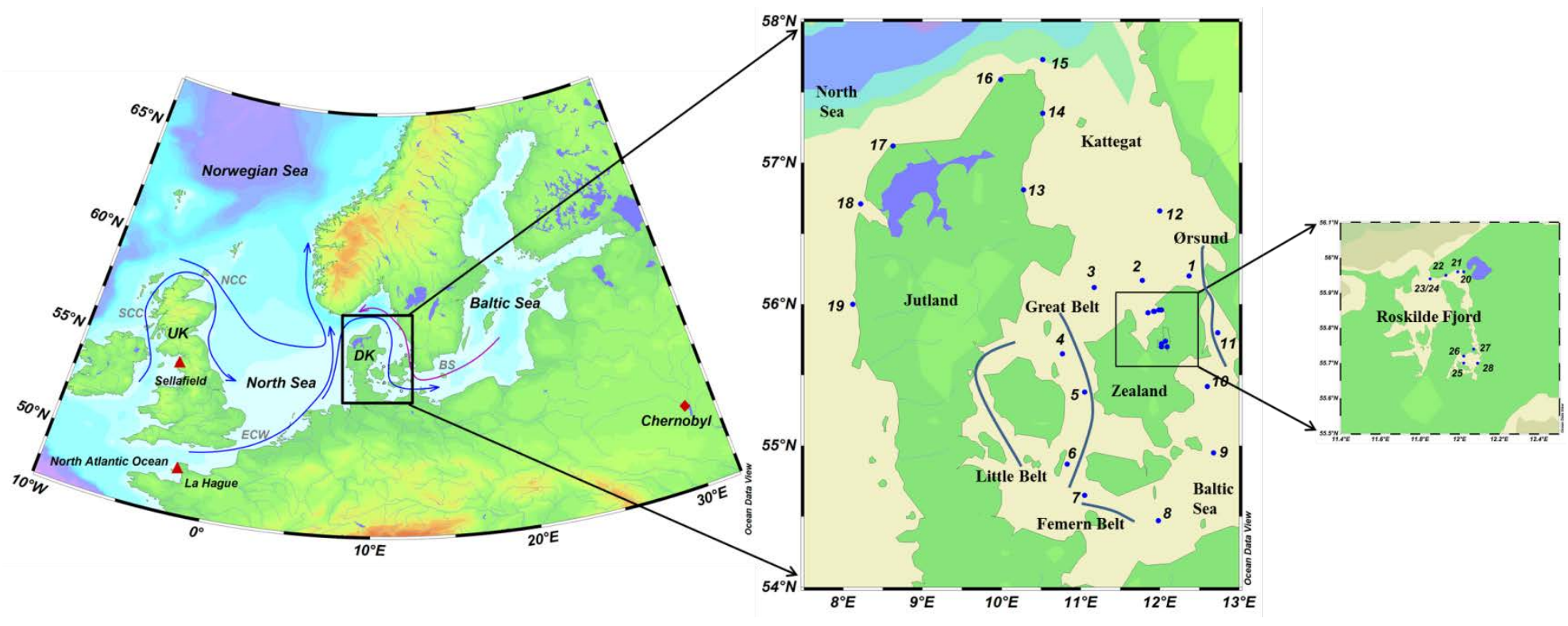


Figure 2. Distribution of ${ }^{236} \mathrm{U}$ concentration (atom/L) in seawater along the Danish coasts in 2013 and $594 \quad 2014$
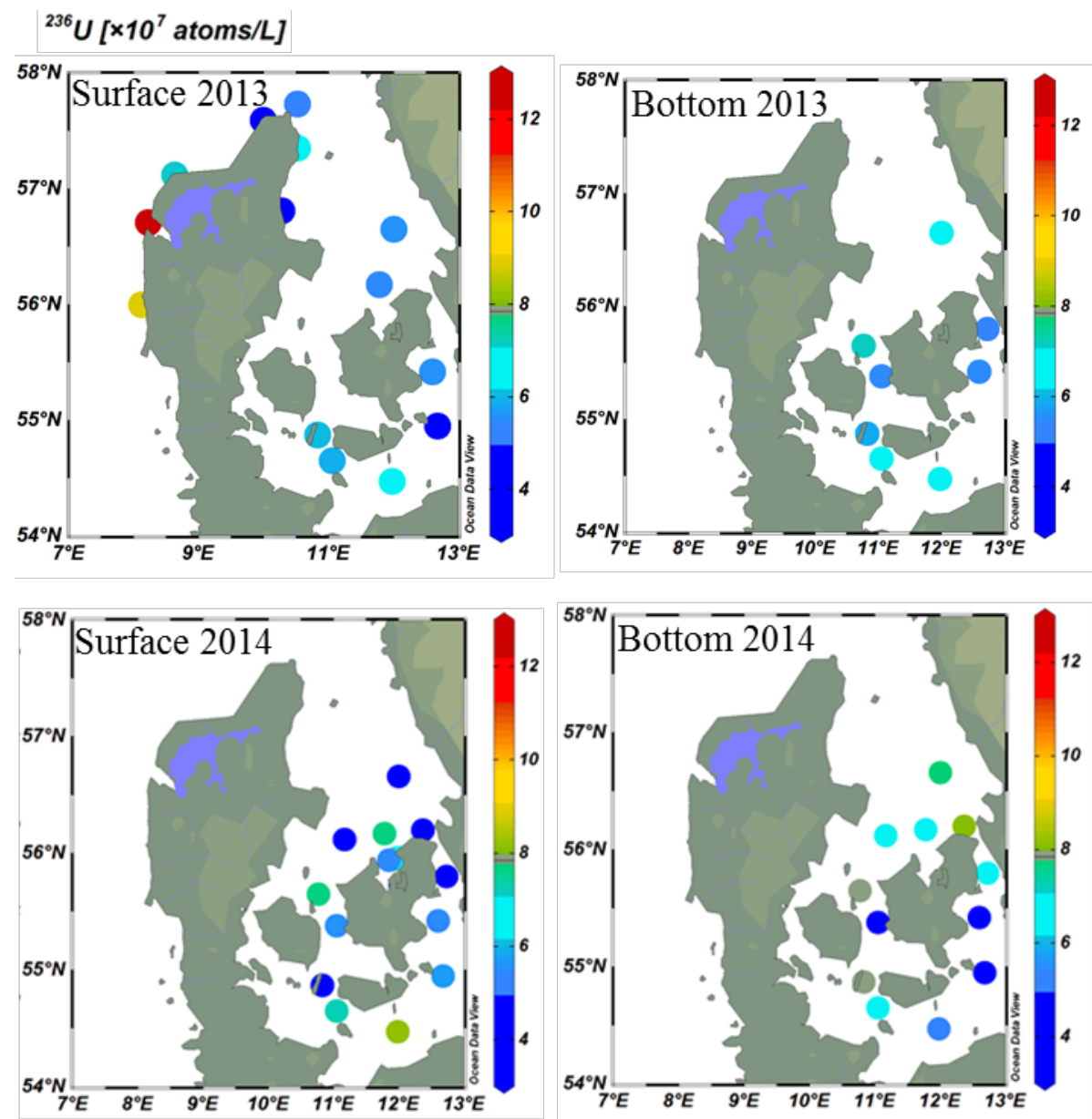
Figure 3. Distribution of ${ }^{236} U /{ }^{238} U$ atomic ratio in seawater along the Danish coasts in 2013 and 2014
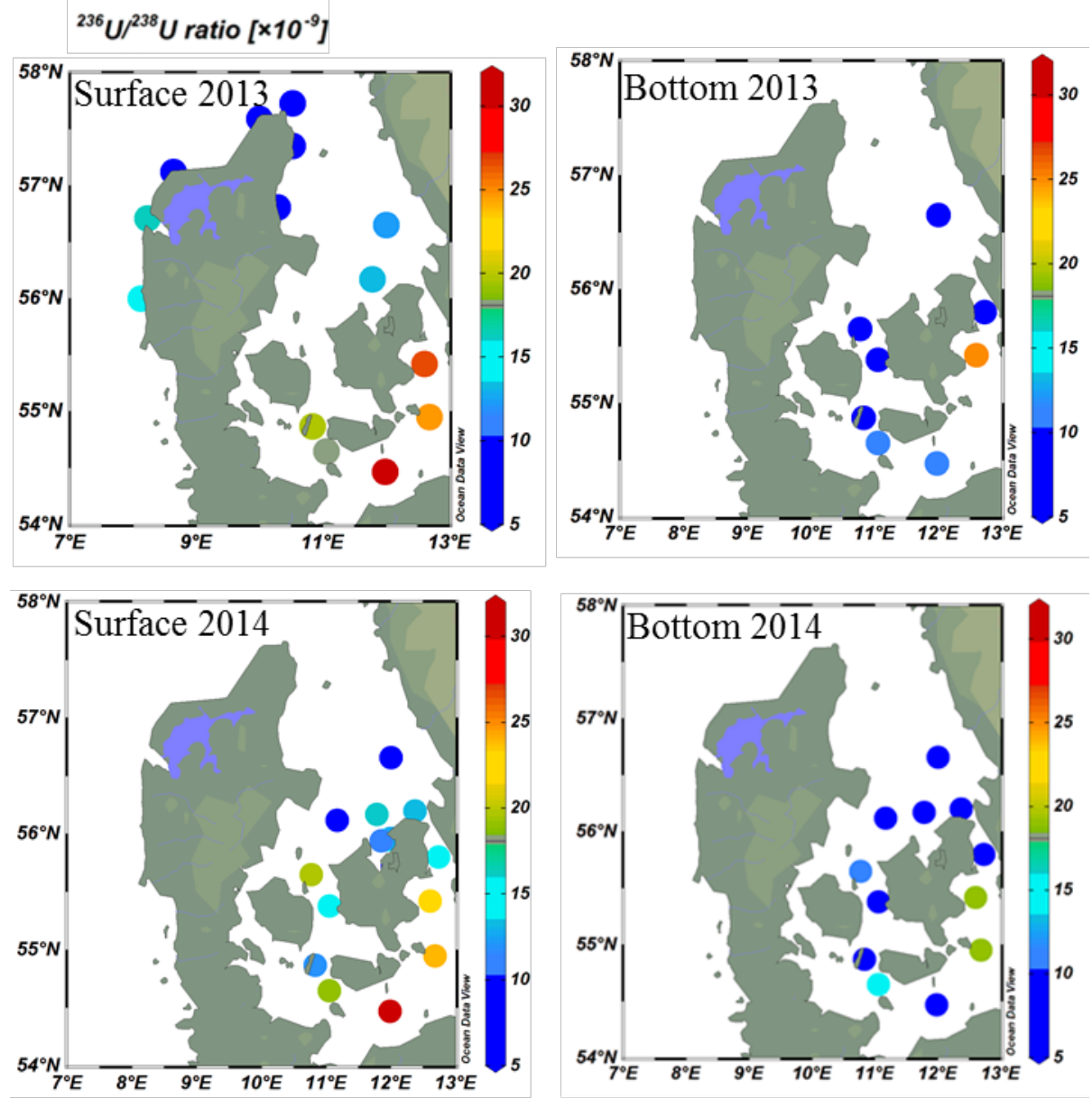
599 Figure 4. Comparison of ${ }^{236} \mathrm{U} /{ }^{238} \mathrm{U}$ atomic ratios in water samples from different locations

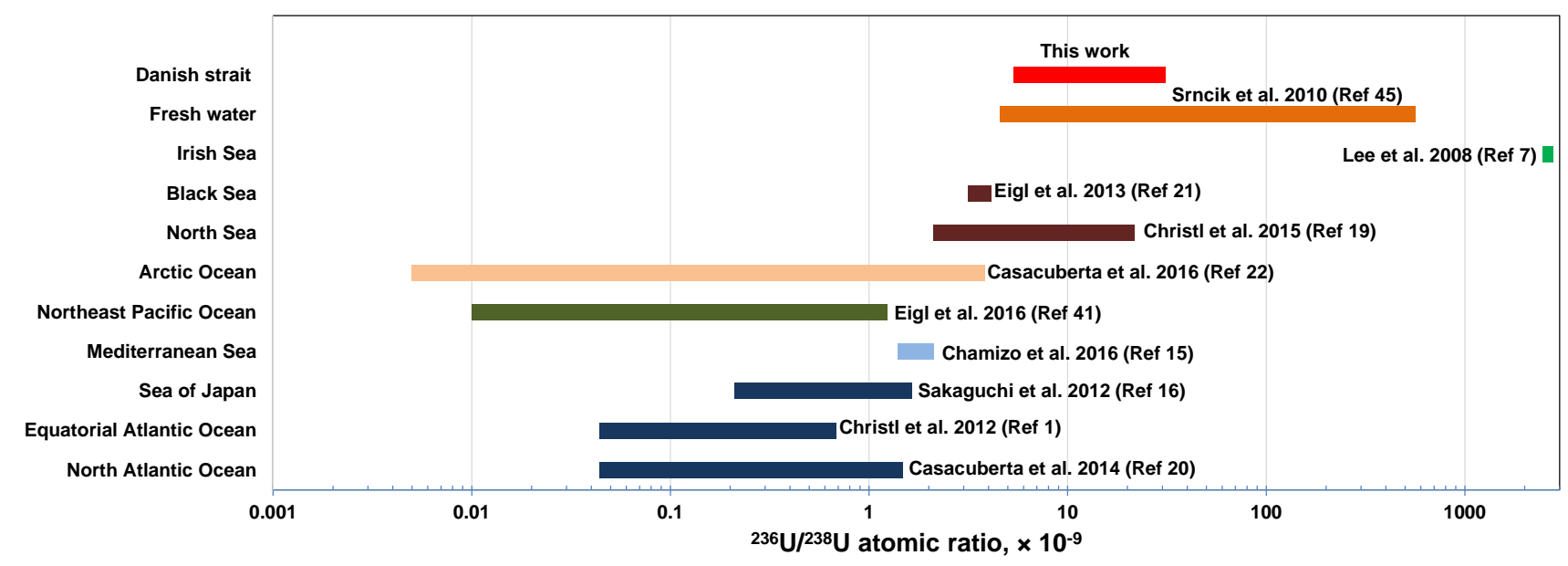

600

601 
602 Figure 5. Correlation ${ }^{238} \mathrm{U}$ and ${ }^{137} \mathrm{Cs}$ concentrations with salinity

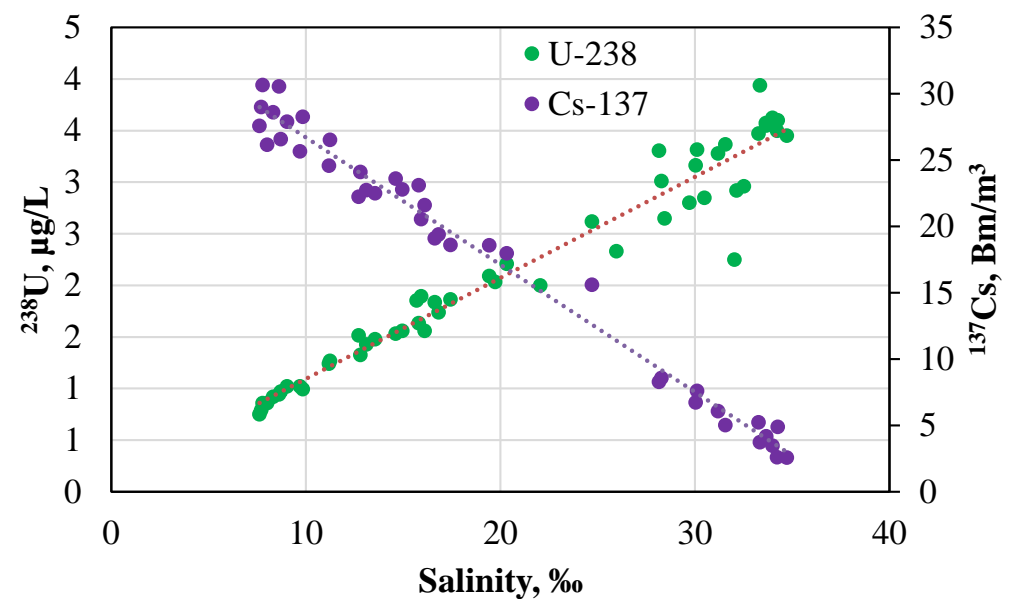

603

604 
Figure 6. Variation of ${ }^{236} \mathrm{U}$ concentrations and ${ }^{236} U /{ }^{238} \mathrm{U}$ atomic ratios with salinity
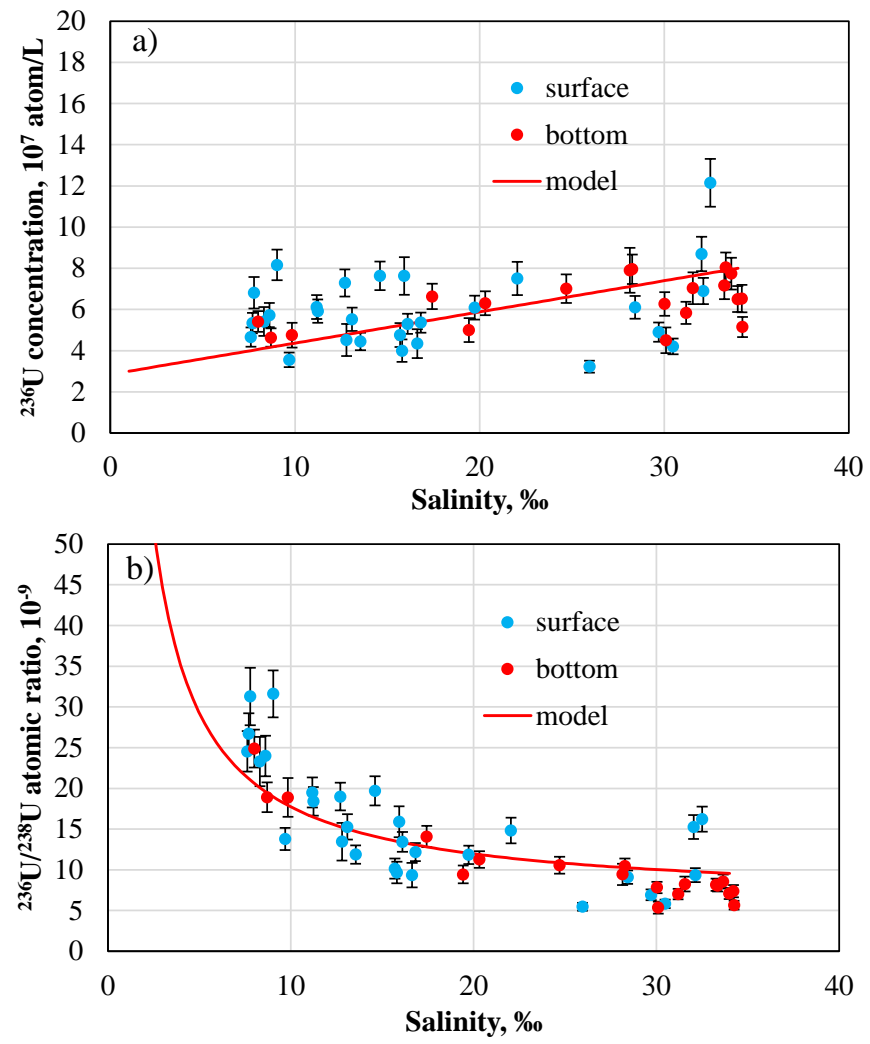
For TOC (Table of Content) only

608

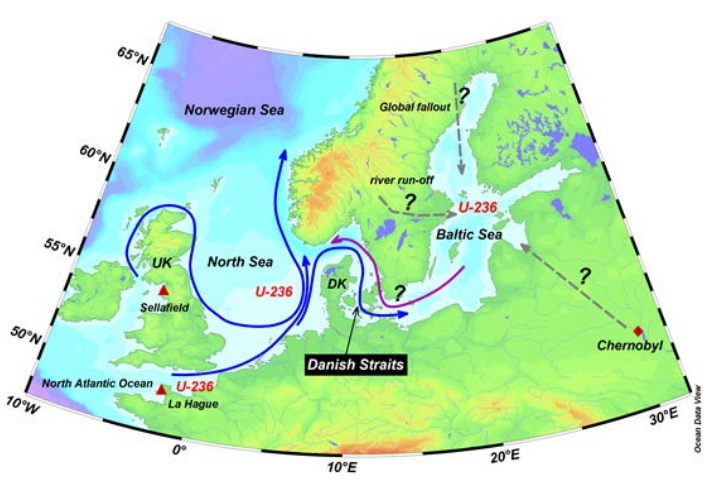

